\title{
The Effect of Liquidity, Leverage, Profitability, and Firm Size on the Bond Rating of Banking Sub Sector in Indonesia Stock Exchange 2014 - 2018
}

\author{
Ayu Lestari \\ Master of Management \\ Mercu Buana University, Jakarta, Indonesia
}

\begin{abstract}
This study aims to detect empirical evidence regarding the effect of liquidity, leverage, profitability and firm size on bond ratings. The population in this study uses banking companies listed on the Indonesia Stock Exchange in the period 2014-2018. The sampling method used was purposive sampling. 10 banking companies that met the criteria were sampled. The data analysis method used is panel data regression analysis. Panel regression analysis model used is the Fixed Effect model. The data used are secondary data in the form of annual financial ratios. The results of this study on the partial test prove that firm size has an effect on bond ratings. The results also showed that liquidity, leverage, profitability had no effect on bond ratings. The simultaneous test results prove that simultaneously liquidity, leverage, profitability and firm size have a significant effect on the bond rating.
\end{abstract}

Keywords:- Bond Rating, Liquidity, Leverage, Profitability, Firm Size.

\section{INTRODUCTION}

The capital market is a place for trading various longterm financial instruments, both in the form of debt and equity, which are issued by the government, public authorities and private companies (Husnan, 2001). One of the financial instruments that are traded and in demand is bonds. The bond itself is a certificate or securities containing a contract between an investor as a funder and the issuer as a borrower. Currently, bond ratings are one of the references for investors in choosing bonds because that is.

With a high rating, the bond issuing company can acquire investors by paying a lower coupon rate because of the lower risk borne by investors. (Ross, et al; 2008).

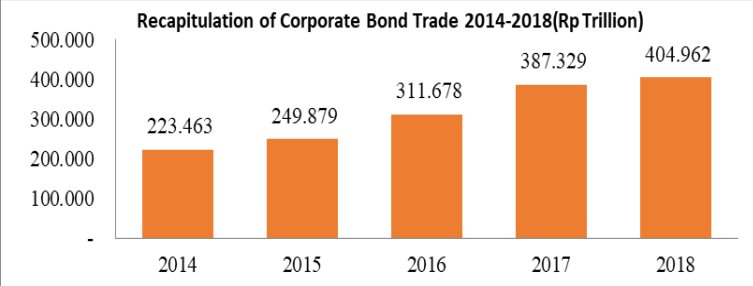

Table 1:- Recapitulation of Corporate Bond Trade 20142018

Source: Statistik pasar modal, Otoritas Jasa Keuangan.

\author{
Andam Dewi Syarif \\ Lecturer at the Faculty of Business and Economics \\ Mercu Buana University, Jakarta, Indonesia
}

The development of bonds in Indonesia is currently showing better results. This can be seen from the value of the bond market capitalization which continues to increase every year. When viewed from the industrial sector, bonds in the capital market are dominated by companies in the financial industry sector.

On the other hand, there are several cases currently occurring that may raise questions about whether the bond rating assessed by the rating agency in Indonesia provides an illustration of the company's actual performance. One of them was in Bank Global in 2004 the bond rating was rated by Kasnic's rating agency with $\mathrm{A}-$, then with the announcement of Bank Indonesia that Bank Global's license was frozen, the bond rating was lowered to D (default). With this, it can be seen that the rating carried out by Kasnic's rating agent is biased or does not reflect the real condition of the company.

This phenomenon raises a question, in Indonesia there have been several issuers that experience default (default) which happen to have an investment grade rating, whether the bond rating that is rated by the rating agency in Indonesia is accurate.

Until now, there is still no certainty from the existing rating agencies regarding the factors that affect the rating of a bond. Several studies on bond ratings that have been conducted have had mixed results. The inconsistency in the factors that influence bond ratings is what encourages researchers to re-verify the factors that affect bond ratings.

\section{THEORY}

\section{A. Capital Struktur Theory}

Capital structure is the first topic in finance, both discussed as a subtopic in corporate finance and in investment decisions. Capital structure is a balance or comparison between foreign (long-term) capital and its own capital. Capital structure is an important problem for companies, because the good or bad of the capital structure will have a direct effect on the company's financial position (Riyanto, 2011).

\section{B. Signaling Theory}

Signaling theory shows the existence of information asymmetry between company management and various interested parties, related to the information released. Information in the form of issued bond ratings is expected 
to signal the company's financial condition and illustrate the possibilities that occur in relation to the debt it has (Raharja and Sari, 2008).

\section{Liquidity Preference Theory}

Fabozzi (2000) implied forward interest rates will not be an unbiased estimate of market expectations of future interest rates because these market expectations include a liquidity premium. So that if the liquidity premium from the interest rate expected in the future is high, investors will invest in the long term.

\section{Bond Rating}

Bond rating is a scale of risk of all bonds traded. This scale shows how safe a bond is for investors. This security is shown by the company's ability to pay interest and repay the loan principal (Linandarini, 2010).

\section{E. Liquidity}

Loan to Deposit Ratio (LDR) as a measuring tool for calculating the liquidity ratio. It is used to assess the liquidity of a bank and also shows the bank's ability to raise funds and channel them back to the public. The standard used by Bank Indonesia for the LDR ratio is $80 \%$ to $110 \%$.

\section{F. Leverage}

The ratio used to measure the extent to which the company's activities are financed with debt (Kasmir, 2010: 151). Debt to Equity Ratio (DER) is a financial ratio that shows the proportion of the entity's capital and debt used to finance the assets of an entity.

\section{G. Profitability}

Return on Assets is one of the profitability ratios that shows the company's ability to earn profits in terms of sales, total assets and profit for its own capital (Alwi, 2012). This ratio aims to measure or assess the company's ability to gain profits through various activities carried out by the company.

\section{H. Firm Size}

In general, large companies have performed well and have a strong position in their respective industries. This has made large companies more trusted to fulfill their bond obligations. (Lopez; 2004).

\section{Thinking Framework}

This research framework is based on research questions and represents several theories and estimates the effect of the independent variable on the dependent. The framework can be explained as follows:

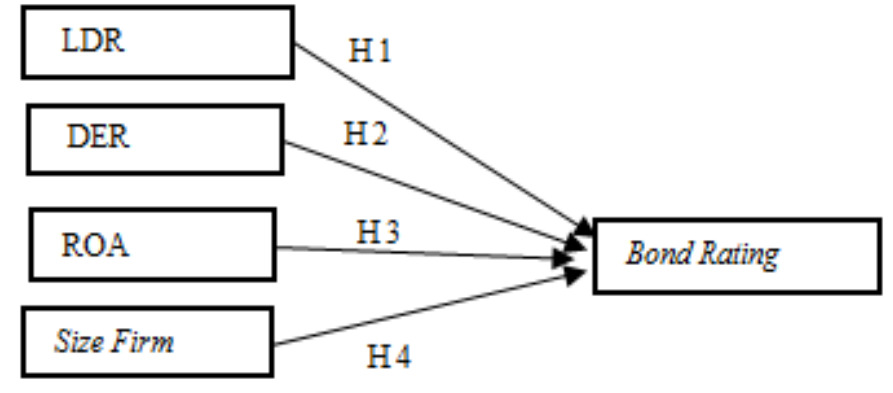

Fig 1:- Theoretical Framework

\section{RESEARCH METHODS}

This research is a quantitative study using the Causality method. The population of this study is bank financial institutions listed on the Indonesia Stock Exchange from 2014 to 2018, totaling 45 banks. The number of samples in this study were 10 banks using purposive sampling with the following requirements: (a) Bank financial institutions whose bonds are listed on the Indonesia Stock Exchange from 2014 to 2018; (b) Companies in the Banking Sub-Sector listed on the Indonesia Stock Exchange; (c) Companies in the Banking Sub-Sector that present complete Annual financial reports for the period 2014 s.d. 2018. The measurement scale used is the ratio scale and nominal scale.

Based on the sample selected for the study were 10 companies, namely as follows:

\begin{tabular}{|c|c|c|}
\hline NO & Company & Code \\
\hline 1. & Bank Rakyat Indonesia, Tbk & BBRI \\
\hline 2. & Bank Central Asia, Tbk & BBCA \\
\hline 3. & Bank Bukopin, Tbk & BBKP \\
\hline 4. & Bank Negara Indonesia,Tbk & BBNI \\
\hline 5. & Bank Mandiri,Tbk & BMRI \\
\hline 6. & Bank Danamon Indonesia, Tbk & BDMN \\
\hline 7. & Bank Permata, Tbk & BNLI \\
\hline 8. & Bank Maybank Indonesia, Tbk. & BNBA \\
\hline 9. & Bank Tabungan Negara (Persero) & BBTN \\
\hline 10. & Tbk. & BACA \\
\hline
\end{tabular}

Table 2:- Research sample

\section{RESULTS AND DISCUSSION}

\section{A. Results}

The data used in this research is panel data, which is a combination of time series and cross section data. Time series data per year for the period 2014 to 2018 to test four independent (free) variables, namely Loan to Deposit Ratio, Debt to Equity Ratio, Return on Assets, Firm size to the dependent variable, namely Bond Rating. has a significant effect on the bond rating. To choose the most appropriate model, several tests were carried out, namely: 


\section{Model Regresi Data Panel}

- Chow Test

\section{Redundant Fixed Effects Tests \\ Equation: Untitled \\ Test cross-section foxed effects}

\begin{tabular}{lrrr}
\hline Effects Test & Statistic & df. & Prob. \\
\hline Cross-section F & 77.987541 & $(9,36)$ & 0.0000 \\
Cross-section Chi-square & 151.013647 & 9 & 0.0000 \\
\hline
\end{tabular}

Table 3:- Chow Test

Based on the results of the Chow Test in the table above, it can be seen that the Chi-square probability is 0.000 smaller than $\alpha 0.05$, so it can be concluded that $\mathrm{H}_{0}$ is rejected and the Fixed Effecst model is more precise than the Common Effect model. When the selected model is Fixed Effects, it is necessary to do the next test, namely the Hausman Test.Uji Hausman (Hausman Test)

\section{- Hausman Test}

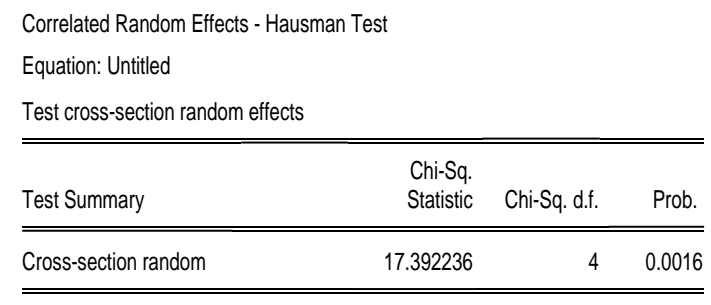

Table 4:- Hausaman Test

Based on the results of the Hausman Test in the table above, it can be seen that the Chi-square probability value is 0.0016 less than 0.05 . So it can be concluded that $\mathrm{H}_{0}$ is rejected, and a more appropriate model to use is the fixed effects model. Because in the Hausman Test the fixed effects model has been selected, there is no need to do the Langrange Multiplier Test (LM Test).

\section{Classical Assumption Test Result}

- Multicollinearity Test Results

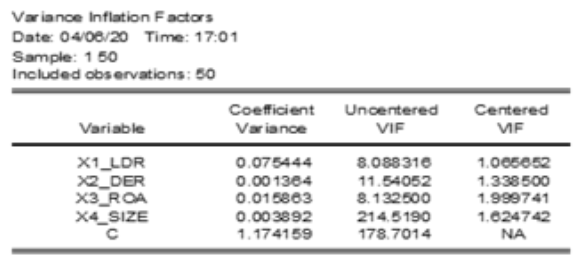

Table 5:- Multicollinearity Test

In the table above, it can be seen that the VIF values for X1, X2, X3 and X4 are smaller than 10, so it can be said that the assumption of multicollinearity has been fulfilled.

\section{- Heteroscedasticity Test Results}

Heteroskedasticity Test: Whit

\begin{tabular}{llll}
\hline \hline F-statistic & 1.751333 & Prob. F(14,35) & 0.0889 \\
Obs*R-squared & 20.59746 & Prob. Chi-Square(14) & 0.1124 \\
Scaled explained SS & 18.44322 & Prob. Chi-Square(14) & 0.1873 \\
\hline \hline
\end{tabular}

Table 6:- Heteroscedasticity Test

Shows the value for Prob. Chi-Square (14) which is $0.1124>0.05$, then the Heteroscedasticity assumption has been fulfilled.

\section{Hypothesis Testing Results}

\section{- Panel Data Regression Equations}

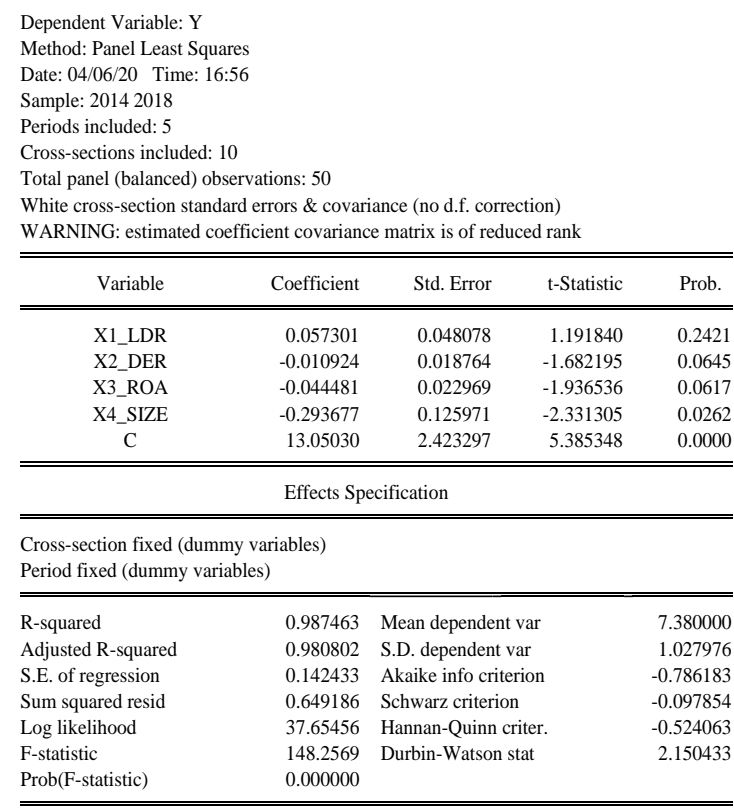

Table 7:- Panel data regression

Based on the Coefficient column in Table 7, the regression equation can be written as follows:

$$
\begin{gathered}
Y=13,05+0,0573 X 1-0,0109 X 2-0,0445 X 3 \\
-0,2937 X 4+\varepsilon
\end{gathered}
$$

From the regression equation, it can be explained that:

The constant $\mathrm{C}$ of 13.05 indicates that if the value of all independent variables is constant $(0)$, then the value of the dependent variable on the bond rating (Y) is 13.05.

The positive regression coefficient for the independent variable Liquidity Ratio $\left(\mathrm{X}^{1}\right)$ indicates that the Liquidity Ratio has a positive relationship with the Bond Rating. The regression coefficient of 0.0573 means that for each increase in the Liquidity Ratio of one unit, the bond rating will increase by 0.0573 units. In this case other factors are considered constant. 
The negative regression coefficient of the independent variable Leverage $\left(X^{2}\right)$ indicates that Leverage has a negative relationship with the Bond Rating. The regression coefficient is 0.0109 , meaning that every one unit increase in leverage, the bond rating will decrease by 0.0109 units. In this case other factors are considered constant.

The negative regression coefficient of the independent variable Profitability $\left(\mathrm{X}^{3}\right)$ shows that the profitability has a negative relationship with the bond rating. The regression coefficient is 0.0445 , meaning that for each increase in profitability by one unit, the bond rating will decrease by 0.0445 units. In this case other factors are considered constant.

The negative regression coefficient for the independent variable firm Size $\left(\mathrm{X}^{4}\right)$ indicates that firm Size has a negative relationship with the Bond Rating. The regression coefficient is 0.2937 , meaning that for each increase in firm Size by one unit, the bond rating will decrease by 0.2937 units. In this case other factors are considered constant.

\section{- $t$ test result}

If the $t$ value of the estimated parameter is greater than the t-table value, then partially the independent variable affects the dependent variable. The results of the $t$ test (partial regression test) can be seen in Table 4.8. By looking at the t-Statistic and Probability column, it can be explained:

The t-count value of the independent variable $\mathrm{X} 1$ is 1.1918 smaller $(<)$ than the t-table value of 1.645 , or the probability value of 0.2421 is greater $(>)$ than $0.05(\alpha=$ $5 \%$ ), that is, it shows that the Liquidity Ratio has no effect on the Bond Rating.

The t-count value of the independent variable $\mathrm{X} 2$ is 1.682 smaller $(>)$ than the t-table value of -1.645 , or the probability value of 0.0645 is greater $(>)$ than $0.05(\alpha=$ $5 \%$ ), That is, this is indicates that leverage has no effect on the Bond Rating.

The t-count value of the independent variable X3 is 1.937 smaller $(<)$ than the t-table value of -1.645 , or the probability value of 0.0617 is greater $(>)$ than $0.05(\alpha=$ $5 \%$ ), that is, this is indicates that Profitability has no effect on the Bond Rating

The t-count value of the independent variable $\mathrm{X} 4$ is 2.331 smaller $(<)$ than the t-table value, namely -1.645 , or the probability value of 0.0262 is smaller $(<)$ than $0.05(\alpha=$ $5 \%$ ), That is, this shows that the size of the company has an influence on the bond rating.

\section{- $\quad$ test Result}

The results of the F test can be seen in the table below. By looking at the F-statistic and Prob (F-statistic) it can be explained that the probability value of 0.0000 is smaller $(<)$ than 0.05 , that is, this shows that the variables of liquidity ratio, leverage, profitability and size are simultaneously has a significant effect on the bond rating.

\begin{tabular}{|c|c|c|c|c|}
\hline $\begin{array}{l}\text { Dependent Variable: } \\
\text { Method: Panel Least } \\
\text { Date: } 04 / 06 / 20 \text { Tim } \\
\text { Sample: } 20142018 \\
\text { Periods included: } 5 \\
\text { Cross-sections incluc } \\
\text { Total panel (balances } \\
\text { White cross-section s } \\
\text { WARNING: estimate }\end{array}$ & $\begin{array}{l}\text { ations: } 50 \\
\text { arors \& covari } \\
\text { ient covarianc }\end{array}$ & $\begin{array}{l}\text { ance (no d.f. correction } \\
\text { e matrix is of reduced }\end{array}$ & $\begin{array}{l}\text { ion) } \\
d \text { rank }\end{array}$ & \\
\hline Variable & Coefficient & Std. Error & t-Statistic & Prob. \\
\hline X1_LDR & 0.057301 & 0.048078 & 1.191840 & 0.2421 \\
\hline $\mathrm{X} 2$ DER & -0.010924 & 0.018764 & -1.682195 & 0.0645 \\
\hline X3_ROA & -0.044481 & 0.022969 & -1.936536 & 0.0617 \\
\hline X4_SIZE & -0.293677 & 0.125971 & -2.331305 & 0.0262 \\
\hline C & 13.05030 & 2.423297 & 5.385348 & 0.0000 \\
\hline \multicolumn{5}{|c|}{ Effects Specification } \\
\hline \multicolumn{5}{|c|}{$\begin{array}{l}\text { Cross-section fixed (dummy variables) } \\
\text { Period fixed (dummy variables) }\end{array}$} \\
\hline R-squared & 0.987463 & Mean dependent var & & 7.380000 \\
\hline Adjusted R-squared & 0.980802 & S.D. dependent var & & 1.027976 \\
\hline S.E. of regression & 0.142433 & Akaike info criterion & & -0.786183 \\
\hline Sum squared resid & 0.649186 & Schwarz criterion & & -0.097854 \\
\hline Log likelihood & 37.65456 & Hannan-Quinn criter. & & -0.524063 \\
\hline F-statistic & 148.2569 & Durbin-Watson stat & & 2.150433 \\
\hline Prob(F-statistic) & 0.000000 & & & \\
\hline
\end{tabular}

Table 8:- F Test Output Results

- Result of Determination Coefficient Test $\left(R^{2}\right)$

Testing the coefficient of determination $\left(\mathrm{R}^{2}\right)$ is basically used to measure how far the model's ability to explain variations in the dependent variable (Ghozali, 2011). The coefficient of determination $R^{2}$ is a number that indicates the proportion or percentage of variation in the dependent variable explained by the independent variable in the regression model.

The results of the determination coefficient test $\left(R^{2}\right)$ can also be seen in the table above. By looking at the Adjusted R-squared it can be explained that the value of the coefficient of determination $\left(\mathrm{R}^{2}\right)$ is 0.987 . That is, this shows that together the variables of liquidity ratio, leverage, profitability and size have a contribution to explain the bond rating by $98 \%$, while the remaining $2 \%$ is explained by other variables that are not researched or not included in this research model.

\section{B. Discussion}

The results of the $t$ test for the liquidity variable as measured by the Loan Deposit to Ratio interpreted that the Liquidity Ratio had no effect on bond ratings, the results of this study were in line with previous research conducted by Agita Putra (2015) which stated that LDR had no effect on bond ratings. In another study conducted by Rizal (2017), it is also stated that LDR has no effect on bond ratings.

The results of the t-test Leverage as measured by the Debt to equity ratio show that leverage has no effect on bond ratings. Thus the results of this study are in line with previous research, Poppy Nurmayanti (2009) and Anita (2017) which state that DER has no effect on bond ratings. A high level of leverage is not good because of the burden of debt interest expense. 
The results of the $t$ test of profitability as measured by Return On Assets show that ROA has no effect on bond ratings. The results of this study are in line with previous research conducted by Shinta (2011) and Agita (2015) which stated that ROA has no effect on bond ratings. This shows that in a state of high or low company profits, there are reasons for the company to issue bond debt.

In this study, the results of the t test of firm size show the effect on bond ratings. This result is supported by Rukmana (2016), which states that even though the size of the company has a high value, it can have a negative effect on the bond rating if the company is subject to "default" default, thereby lowering the bond's rating. according to the theory of Spence (1973), that firm size can give a signal to the correct bond rating is proven by giving a negative signal. So it can be said that company size has a significant negative effect on bond ratings.

\section{CONCLUSIONS \& SUGGESTION}

\section{A. Conclusions}

Based on the results of the research that has been done, it can be concluded as follows:

$>$ Liquidity as measured by the Loan to Deposit Ratio has no effect on the bond rating.

$>$ Leverage as measured by Debt to Equity Ratio has no effect on bond ratings

$>$ Profitability as measured by the Return on Asset ratio has no effect on the bond rating

$>$ Firm size has a positive and significant effect on bond ratings.

\section{B. Suggestion}

Following are suggestions that can be used as a reference for future research:

The results of this study are expected to assist investors in analyzing financial statements. Specifically, financial ratios such as LDR, DER, ROA, and firm Size have a significant effect on bond ratings. For this reason, before investors decide to invest in bonds, they can analyze these ratios to find out a picture of bank performance and study the development of the ups and downs of bond ratings so that investors can decide to invest in a bank appropriately and steadily.

$>$ For companies, the results in this study indicate that simultaneously the ratios used in research such as LDR, DER, ROA and firm size affect bond ratings and partially only firm size affects bond ratings, so it is advisable for banks to pay attention to the level of these ratios are to maintain stability or improve bond ratings. By maintaining the health of the banking system, it can also maintain bank stability in facing the risk of default (default) and asset freezing by Bank Indonesia.

$>$ For further research, with this research, it is hoped that further researchers will be able to conduct further research related to adding variables that affect bond ratings such as growth, guarantees, age of bonds and auditor reputation.

\section{REFERENCES}

[1]. Aduardus, Tandelilin. 2015. Portfolios and Investments. Yogyakarta: Conisius.

[2]. Agus D. Hardjito, Martono. 2002. Financial Management, First Edition, Ekonisia, Yogyakarta.

[3]. Alwi, Z. Iskandar. 2010. Capital Market Theory and Applications. Jakarta: Pancar Siwah Foundation.

[4]. Brigham, Eugene F and Houston. 2006. Fundamental of Financial Management: Basics of Financial Management. Edition 10. Jakarta: Four Salemba.

[5]. Eny Dwi Maharti and Daljono. 2011. Analysis of Factors Affecting Bond Ratings.

[6]. Fabozzi, J. Frank. 2000. Investment Management. Translation: The Salemba Empat Language Transfer Team. Book 2. Jakarta: Four Salemba.

[7]. Ghozali, Imam. 2013. Application of Multivariate Analysis with the IBM SPSS 21 Program. Edition 7. Semarang: Diponegoro University.

[8]. Hanafi, M.M, and A. Halim. 2004. Financial Statement Analysis. Second Edition. Publishing and Printing Unit. Yogyakarta.

[9]. Ibrahim, Amen. 2008. Theory and Concept of Public Service and Its Implementation. Jakarta: Mandar Maju.

[10]. Cashmere. 2008. Banks and Other Financial Institutions. 2008 Revised Edition. Jakarta: PT. RAJAGRAFINDO PERSADA.

[11]. Mc Donald, S. Scott and Timoty W. Koch. 2016. Management Of Bank. Sixth Edition. Thomson South Western. USA.

[12]. N. Agus Sunarjanto and Daniel Tulasi. "The Ability of Financial Ratios and Corporate Governance to Predict Bond Ratings in Consumer Goods Companies", Journal of Finance and Banking, Vol. 17, No.2 May 2013, p. 230-242.

[13]. Linandarini, Ermi. 2010. "The Ability of Financial Ratios in Predicting the Rating of Indonesian Company Bonds." Essay. Semarang: Faculty of Economics. UNDIP.

[14]. Ross, et al. 2008. Corporate Finance Fundamentals, Mc- GrawHill International Edition.

[15]. Rukmana, L.N (2016). The Effects of Financial Ratios and Firm Size on The Bond Ratings of Banking Companies Listed in Indonesia Stock Exchange in 2011-2015. Jurnal Pendidikan dan ekonomi, 5(6).

[16]. Suad Husnan. 2001. Financial Management Theory and Applications. Yogyakarta. BPFE.

[17]. Snyder, C. R., \& Lopez (2007). Positive Psycyhology in Scientic and Practical Exploration of Human Strength. London: Sage Publication

[18]. Spence, Michael. 1973. Job Market Signaling. The Quarterly Journal of Economics, Vol. 87, No. 3. (Aug., 1973), pp. 355-374.

[19]. Raharja and Sari. 2008. "The Ability of Financial Ratios in Predicting Bond Ratings (PT Kasnic Credit Rating)." Maksi Journal, Vol. 8.

[20]. Linandarini, Ermi. 2010. "The Ability of Financial Ratios in Predicting the Rating of Indonesian Company Bonds." Essay. Semarang: Faculty of Economics. UNDIP 